\title{
A missing piece between Laurentia and the North China Craton in Rodinia: evidence from detrital zircons from metasedimentary rocks of the North Qinling Terrane in central China
}

\author{
FANG-YUAN SUN, SHAO-BING ZHANG, YONG-FEI \\ ZHENG, ZHEN-XIN LI AND TING LIANG
}

CAS Key Laboratory of Crust-Mantle Materials and Environments, School of Earth and Space Sciences, University of Science and Technology of China

Presenting Author: sunfy16@mail.ustc.edu.cn

Microcontinents are small but not trivial in supercontinent reconstruction because they might be key bridges connecting major blocks. The North Qinling Terrane is a microcontinent between the North China Craton and South China Block. It subducted beneath the North China Craton for regional metamorphism in the Early Paleozoic. In order to constrain its evolution in supercontinent Rodinia, metasedimentary rocks were studied for whole-rock major and trace elements as well as zircon $\mathrm{U}-\mathrm{Pb}$ ages and Lu-Hf isotopes. The metasedimentary rocks show greywacke compositions with A/CNK ratios of 0.99 1.28 and upper continental crust-like trace element patterns. They have metamorphic ages of ca. 510-490 Ma, recording continental collision for the regional metamorphism. The youngest detrital zircon $\mathrm{U}-\mathrm{Pb}$ ages from three metasedimentary rocks are $1161 \pm 54 \mathrm{Ma} \quad 954 \pm 15 \mathrm{Ma} \quad 861 \pm 10 \mathrm{Ma}$, respectively. In combination with ages of granitic intrusions of 890 to $960 \mathrm{Ma}$ in the target region, their deposition ages are constrained to be 1110-960 Ma, ca. $960 \mathrm{Ma}$ and ca. $860 \mathrm{Ma}$, respectively. The cumulative proportions of the difference between the detrital zircon crystallization ages and the deposition ages for the sediments of ca. $960 \mathrm{Ma}$ and ca. $860 \mathrm{Ma}$ suggest their deposition in an accretionary or collisional setting. Detrital zircon age spectrum yields two major populations at 1000-900 Ma and 1700-1400 Ma and three subordinate populations at 900-800 Ma, 1300-1200 Ma and 1800-1700 Ma with rare Neoarchean grains. Neoproterozoic detrital zircons mainly have negative $\varepsilon \mathrm{Hf}(\mathrm{t})$ values, consistent with Neoproterozoic granitoids in the North Qinling Terrane. On the other hand, Mesoproterozoic detrital zircons mainly have positive $\varepsilon \mathrm{Hf}(\mathrm{t})$ values, similar to those in East Laurentia and East Greenland. This means that the major provenance of sediments in the Qinling Group was the North Qinling Terrane itself and East Laurentia, supporting the connection between the North Qinling Terrane and East Laurentia in Rodinia prior to its breakup. In combination with the coeval strata in the southern margin of the North China Craton, we propose that the North Qinling Terrane is a missing piece connecting the southern margin of the North China Craton with the northern part of East Laurentia in Rodinia in the early Neoproterozoic. 